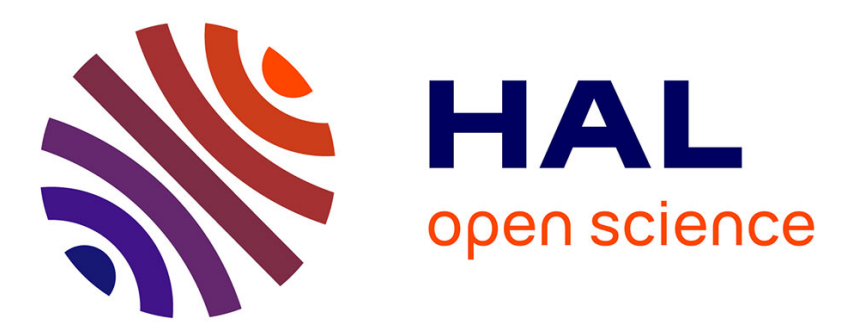

\title{
Study of the nitridation process of TiSi2 powder
}

Laurence Maillé, M.A. A Dourges, S. Le Ber, P. Weisbecker, F. Teyssandier, Y. Le Petitcorps, R. Pailler

\section{To cite this version:}

Laurence Maillé, M.A. A Dourges, S. Le Ber, P. Weisbecker, F. Teyssandier, et al.. Study of the nitridation process of TiSi2 powder. Applied Surface Science, 2012, 260, pp.29 - 31. 10.1016/j.apsusc.2012.01.023 . hal-01845106

\section{HAL Id: hal-01845106 https://hal.science/hal-01845106}

Submitted on $20 \mathrm{Jul} 2018$

HAL is a multi-disciplinary open access archive for the deposit and dissemination of scientific research documents, whether they are published or not. The documents may come from teaching and research institutions in France or abroad, or from public or private research centers.
L'archive ouverte pluridisciplinaire HAL, est destinée au dépôt et à la diffusion de documents scientifiques de niveau recherche, publiés ou non, émanant des établissements d'enseignement et de recherche français ou étrangers, des laboratoires publics ou privés. 


\title{
STUDY OF THE NITRIDATION PROCESS OF TiSi 2 POWDER
}

\author{
L. Maillé*, M.A. Dourges, S. Le Ber, P. Weisbecker, F. Teyssandier, Y. Le Petitcorps, R. Pailler \\ University of Bordeaux, LCTS, UMR 5801, 33600 Pessac, France
}

This paper reports on the nitriding process of $\mathrm{TiSi}_{2}$ micro/submicrometer-sized powders. $\mathrm{TiSi}_{2}$ powders were treated under nitrogen flow, at $1100^{\circ} \mathrm{C}$, during various durations. The composition and morphology of the nitride powders are characterized by X-ray diffraction and observed on cross-section, prepared using ion polishing system by scanning electron microscopy whereas the chemical composition is analyzed by energy dispersive X-ray spectroscopy. All these analyses revealed that under nitrogen flow, $\mathrm{TiSi}_{2}$ grains are first transformed into a core-shell structure composed of TiN, surrounding by $\mathrm{Si}$. Long nitriding treatments result in the complete transformation of $\mathrm{Si}_{3} \mathrm{~N}_{4}$. These results are discussed in terms of various diffusion limitation phenomena.

Keywords : CMC, milling, powder, XRD

\section{INTRODUCTION}

Ceramic Matrix Composites are developed for aeronautic and spatial applications [1]. Due to their refractoriness and their low density they are used in the hot parts of engines. These composites are usually elaborated by infiltrating a weaved preform by chemical vapor infiltration to form a ceramic matrix. Other processes can also be used to form the matrix. In particular ceramic processes in which a slurry impregnation including filler powder and liquid polymer impregnation can be used [2-7]. The active fillers are aimed at reducing the volume shrinkage resulting from the pyrolytic conversion of polymer to ceramic [8-9]. Titanium disilicide $(\mathrm{d}=4.01 \mathrm{~g} / \mathrm{cc})$ is identified as interesting active filler: under nitrogen atmosphere, the nitridation of $\mathrm{TiSi}_{2}$ starts in a temperature range around $1000^{\circ} \mathrm{C}$ to form $\mathrm{TiN}(\mathrm{d}=5.43 \mathrm{~g} / \mathrm{cc})$ and $\mathrm{Si}_{3} \mathrm{~N}_{4}(\mathrm{~d}=3.19 \mathrm{~g} / \mathrm{cc})$ [10]. This reaction generates a $57 \%$ volume increase. In this paper, we explore the influence of temperature and duration on the nitriding rate of a micro and submicrometer-sized $\mathrm{TiSi}_{2}$ powder.

\section{MATERIALS AND EXPERIMENTAL PROCEDURES}

A high purity micrometer-sized $\mathrm{TiSi}_{2}$ powder (C-54 stable phase, $99.95 \%$ in purity, $\sim 45 \mu \mathrm{m}, \mathrm{Neyco}$ ) is used. The raw powder is milled with a vibratory mixer mill (Retsch MM200) and with planetary ball mill (Retsch PM200). Nitriding process is carried out in a thermogravimetric analyser (Setaram TAG24) or in a furnace using alumina crucibles. This powder is heated under a flow of nitrogen gas $(50 \mathrm{~mL} / \mathrm{min})$ from $20^{\circ} \mathrm{C}$ to $1100^{\circ} \mathrm{C}$ at a heating rate of $10^{\circ} \mathrm{C} / \mathrm{min}$, during various durations $(45 \mathrm{~min}$, 5h, 50h). The crystallographic structure is studied by XRD in Bragg-Brentano geometry, with a Bruker D8 Advance diffractometer, using a copper anode $\left(\mathrm{CuK}_{\alpha}\right)$ and a one-dimensional position sensitive silicon strip detector (Bruker, Linxeye). XRD patterns are recorded using a step size of $0.01^{\circ}$ for the $2 \theta$ range $10-90^{\circ}$, and a counting time of $0.3 \mathrm{~s}$ per step. Sections of nitrided $\mathrm{TiSi}_{2}$ grains are prepared using ion polishing system (Cross Polisher JEOL Ltd). These sections are observed with a FEI Quanta 400 FEG scanning electron microscope whereas the chemical composition is analyzed by EDX (EDAX Genesis XM4), operated at 5kV (interaction volume of roughly $150 \mathrm{~nm}$ wide in this condition). Specific surface areas are determined by the BET method with an ASAP 2010 (Micromeritics); the samples are degassed by heating at $220^{\circ} \mathrm{C}$ during $4 \mathrm{~h}$ immediately prior to measurements.

\section{RESULTS AND DISCUSSION}

\subsection{Nitriding process of micrometer-sized $\mathrm{TiSi}_{2}$ powder}

* Corresponding author: Tel. +33-5-5684-4712.

E-mail address: maille@Icts.u-bordeaux1.fr (L. Maille) 
Powder is analyzed by XRD. Pattern is analyzed using the Rietveld [2] whole profile fitting method with the software Fullprof [3]. Results indicate that the powder is composed of $4.2( \pm 0.7) \%$ wt of free silicon (ICDD-PDF 04-001-7247) and 95.8\%wt of $\mathrm{TiSi}_{2}$ compound (ICDD-PDF 04-0071144).A low specific surface area of $0.33 \mathrm{~m}^{2} / \mathrm{g}$ was measured by the BET method.

According to the Ti-Si-N phase diagram [10-10], the partial nitridation of $\mathrm{TiSi}_{2}$ is resumed by the equation 1 and respectively the complete nitridation of $\mathrm{TiSi}_{2}$ by the equation 2 .
$2 \mathrm{TiSi}_{2}(\mathrm{~s})+\mathrm{N}_{2}(\mathrm{~g}) \rightarrow 2 \mathrm{TiN}(\mathrm{s})+4 \mathrm{Si}(\mathrm{s})$
$(\Delta \mathrm{W} / \mathrm{W} 0=13.5 \%)$
Eq. (1)
$6 \mathrm{TiSi}_{2}(\mathrm{~s})+11 \mathrm{~N}_{2}(\mathrm{~g}) \rightarrow 6 \mathrm{TiN}(\mathrm{s})+4 \mathrm{Si}_{3} \mathrm{~N}_{4}(\mathrm{~s}) \quad(\Delta \mathrm{W} / \mathrm{W} 0=49.4 \%)$
Eq. (2)

The nitriding of powders are performed in a thermogravimetric analyser at three temperatures; $1100^{\circ} \mathrm{C}, 1200^{\circ} \mathrm{C}$ and $1300^{\circ} \mathrm{C}$. The variations of mass gain versus time are presented on figure 1.

XRD patterns (figure 2) and mass gains revealed different behaviours in the different conditions. At $1100^{\circ} \mathrm{C}$ partial nitriding reaction occurs with a mass gain less than $13.5 \%$ and the presence of residual $\mathrm{TiSi}_{2}$ is revealed by XRD analysis. The Eq. 1 formulates this partial reaction with formation of $\mathrm{TiN}$ and $\mathrm{Si}$. Above $1200^{\circ} \mathrm{C}$ a higher mass gain is observed, due to a total nitriding reaction of $\mathrm{TiSi}_{2}$ (Eq. 1) and partial nitriding reaction of silicon (Eq. 2) leading to the formation of both nitrides TiN and $\mathrm{Si}_{3} \mathrm{~N}_{4}$. The amount of $\mathrm{Si}_{3} \mathrm{~N}_{4}$ phase is probably too low to be revealed by the XRD pattern. This reaction is more efficient at $1300^{\circ} \mathrm{C}$, with a higher conversion rate, peaks of $\mathrm{Si}_{3} \mathrm{~N}_{4}$ are clearly observed by XRD analysis (figure 2 ). These results show a two-step nitridation of $\mathrm{TiSi}_{2}$, as it was previously reported in literature [11-12].

Sections of nitrided $\mathrm{TiSi}_{2}$ grains at $1100^{\circ} \mathrm{C}$ during $5 \mathrm{~h}$, are observed by SEM (figures $3 \mathrm{a}, \mathrm{b}$ ). EDX measurements also confirm the presence of TiN and $\mathrm{Si}$. TiN is located at the extreme surface of the $\mathrm{TiSi}_{2}$ powder. A thin discontinuous layer of around $60 \mathrm{~nm}$ is formed; it is composed of nanograins, of approximately $15 \mathrm{~nm}$ wide. TiN is also located along the porosity surface inside the grain. Free metallic silicon seems to precipitate at the grain periphery, between the $\mathrm{TiSi}_{2}$ (observed by $\mathrm{SEM}$ in the center) and the TiN compounds. Free silicon embeds $\mathrm{TiSi}_{2}$ and it is respectively covered by the TiN layer. Nevertheless, for smaller particules (diameter $<3 \mu \mathrm{m}$ ), $\mathrm{TiSi}_{2}$ is completely transformed according to the reaction 1 (figure $3 b$ ).

Some thermodynamic studies in the Ti-Si-N ternary system indicate that $\mathrm{TiSi}_{2}$ can be nitrided into $\mathrm{TiN}$ and $\mathrm{Si}_{3} \mathrm{~N}_{4}$ at $1100^{\circ} \mathrm{C}$ [4-10]. This assertion is not confirmed by our first experiments, even after $5 \mathrm{~h}$ of nitridation at $1100^{\circ} \mathrm{C}$. So, it has been decided to mill the as received powders, with the intention of getting close to a submicronic scale. We expected that the total nitriding reaction of milled powders can occur at lower temperatures in order to get $\mathrm{Si}_{3} \mathrm{~N}_{4}$.

\subsection{Milling study}

The $\mathrm{TiSi}_{2}$ commercially powders are milled with a vibratory ball mill or a planetary ball mill in order to get sub-micronic particles. Results are shown in Table 1.

Thermogravimetric analyses were then performed on these milled powders at $1100^{\circ} \mathrm{C}$ (figure 4 ). The milling improved significantly the nitridation rate, with a weight gain of $8.6 \%$ after $5 \mathrm{~h}$ at $1100^{\circ} \mathrm{C}$. Nitridation of planetary milled powder starts at a clearly lower temperature of $650^{\circ} \mathrm{C}$, with a much steeper slope during the heating stage. Furthermore after planetary milling the weight gain of $\mathrm{TiSi}_{2}$ nitriding reaction reached the value of $29.5 \%\left(5 \mathrm{~h}\right.$ at $\left.1100^{\circ} \mathrm{C}\right)$. This indicated the formation of $\mathrm{Si}_{3} \mathrm{~N}_{4}$. XRD analyses of the powders were performed on the powders treated within the thermogravimetric device (Figure 5). XRD patterns of all nitrided products indicate the presence of $\mathrm{TiN}$ and $\mathrm{Si}$. The XRD pattern of the $\mathrm{TiSi}_{2}$ powder nitrided after planetary milling also exhibits small peaks corresponding to the $\alpha-\mathrm{Si}_{3} \mathrm{~N}_{4}$ and $\beta-\mathrm{Si}_{3} \mathrm{~N}_{4}$ phases.

\section{CONCLUSION}


Our experiments confirm that the complete nitridation of $\mathrm{TiSi}_{2}$ at $1100^{\circ} \mathrm{C}$ is discribed by two steps: the precipitations of free silicon and TiN followed by the nitridation of the free silicon.

It was observed that decreasing the grain size allows to lower the nitriding temperature to form $\mathrm{Si}_{3} \mathrm{~N}_{4}$. For instance in the case of raw powders, the formation of $\mathrm{Si}_{3} \mathrm{~N}_{4}$ starts above $1200^{\circ} \mathrm{C}$ while for planetary milled powder the reaction begins at $1100^{\circ} \mathrm{C}$ after five hours of treatment.

\section{REFERENCES}

1. R. Naslain, Int. J. Appli. Ceram. Technol. 2 (2005) 75-84

2. H.M. Rietveld, J. Appl. Cryst. 2 (1969) 65

3. J. Rodriguez-Carvajal, Physica B: Condens. Matter 192 (1993) 55

4. S. Sambasivan, W.T. Petuskey, J Mater. Res. 9 (1994) 2362 - 2369

5. M. Paulasto, J.K. Kivilahti, F.J.J. Van Loo, J. Appl. Phys. 77 (1995) 4412 - 4416

6. X. Ma, C. Li, W. Zhang, J. edited by W. Krenkel and J. Lamon (2010) 119-125

7. S. Le Ber, M.A. Dourges, L. Maillé, R. Pailler, A. Guette, Ceramic Transactions 215 (2010) 113-123

8. P. Greil, J.Am.Ceram.Soc., 78 (1995) 83 -848

9. P. Greil, J.Eur.Ceram.Soc., 18 (1998) 1905-1914

10. X. Ma, C. Li, W. Khang, Journal of Alloys and Compounds, 394 (2005) 138-147

11. J.M. Cordoba, M.D. Alcalà, M.J. Sayagués, M.A. Avilés, C. Real, and F.J. Gotor, Nitriding Intermetallics, 16 (2008) 948-954

12. R. Beyers, R. Sinclair, and M.E. Thomas, J. Vac. Sci. Technol., B 2 (1984) 781-784

\section{List of figure and table captions}

Figure 1. Thermogravimetric curves of $\mathrm{TiSi}_{2}$ commecialy powder heated at various temperatures within $\mathrm{N}_{2}$ atmosphere

Figure 2. XRD patterns of the starting powder and after TGA experiments in $\mathrm{N}_{2}$.

$(\bullet) \mathrm{TiSi}_{2}$ (ICDD-PDF 04-007-1144); ( $\Delta$ ) Si (ICDD-PDF 04-001-7247) (匹)TiN (ICDD-PDF 04-0021925); ( $\mathbf{\Delta}) \beta-\mathrm{Si}_{3} \mathrm{~N}_{4}(\mathrm{ICDD}-\mathrm{PDF}$ 04-007-2386)

Figure 3. Backscattered electrons SEM images of transverse sections of two grains nitrided during $5 \mathrm{~h}$ at $1100^{\circ} \mathrm{C}$

Figure 4. Thermogravimetric curves of $\mathrm{TiSi}_{2}$ milled and raw powders heated to $1100^{\circ} \mathrm{C}$ into $\mathrm{N}_{2}$ atmosphere

Figure 5. XRD patterns after TGA experiments at $1100^{\circ} \mathrm{C}$ in $\mathrm{N}_{2}$ on raw and milled powders. $(\bullet) \mathrm{TiSi}_{2} ;(\Delta) \mathrm{Si} ;(\mathbf{\square}) \mathrm{TiN} ;(\boldsymbol{\Delta}) \alpha$ and $\beta-\mathrm{Si}_{3} \mathrm{~N}_{4}$

Table 1. Specific surface area and granulometry of raw powders and milled powders. 
Figure 1

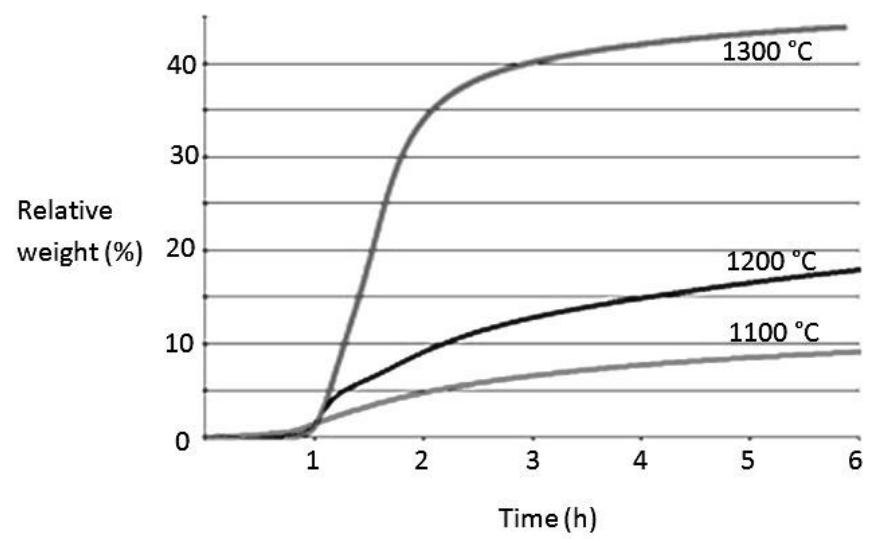

Figure 2



Figure 3
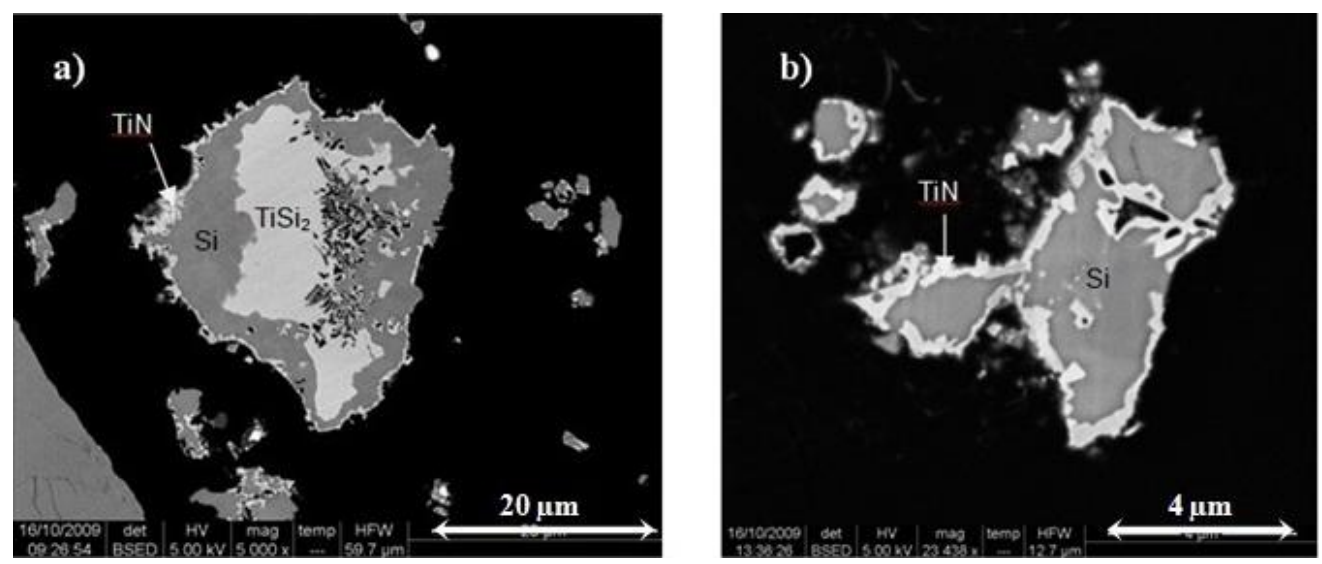


\section{Figure 4}

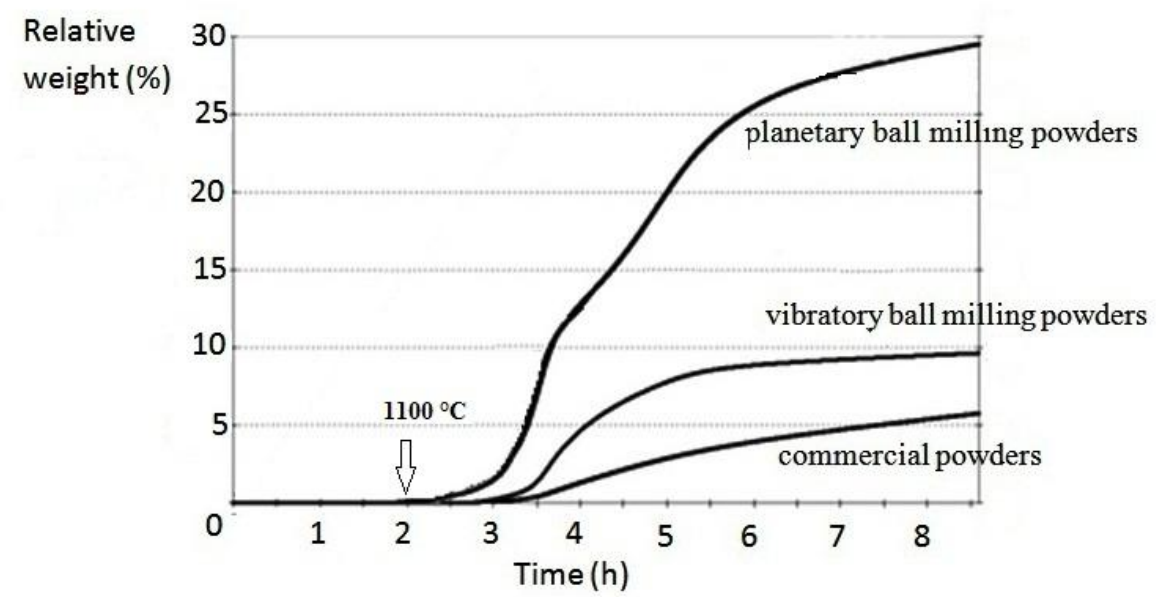

Figure 5

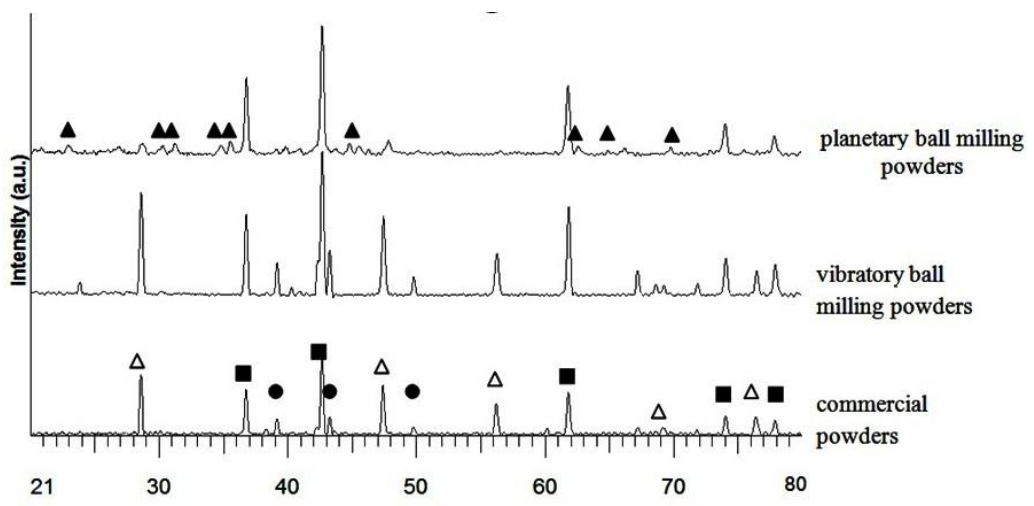

\section{Table 1}

\begin{tabular}{|l|l|l|l|}
\cline { 2 - 4 } \multicolumn{1}{c|}{} & $\begin{array}{l}\text { commercial } \\
\text { powders }\end{array}$ & $\begin{array}{l}\text { vibratory ball } \\
\text { milling } \\
\text { powders }\end{array}$ & $\begin{array}{l}\text { planetary ball } \\
\text { milling powders }\end{array}$ \\
\hline Specific area $\mathrm{S}\left(\mathrm{m}^{2} / \mathrm{g}\right)$ & 0.3 & 2.0 & 41 \\
\hline Mean size $\mathrm{d}_{50}$ & $45 \mu \mathrm{m}$ & $2 \mu \mathrm{m}$ & $550 \mathrm{~nm}$ \\
\hline
\end{tabular}

